\title{
LEPROMIN-LIKE ACTIVITY OF NORMAL SKIN TISSUE
}

\author{
T. F. DAVEY, O.B.E., M.D., M.S.C., and
}

S. E. DREWETT, F.I.M.L.T.

\section{Leprosy Service Research Unit, Uzuakoli, E. Nigeria}

Kooij and Gerritsen $(1956,1958)$ have reported a number of experiments in which skin reactions apparently identical with lepromin reactions were obtained by the use of extracts and suspensions of normal tissue. Many leprologists would consider their early findings inconclusive, suggestive more of personal idiosyncrasy than of typical lepromin reactivity, and would consider the comments of Kinnear Brown, Murray Short and Blenska (1957) very much to the point. In some of the later experiments however, reactions were described which were as pronounced as those to be expected with a standard lepromin preparation, though here again the occurrence of macroscopic reactions among lepromatous cases introduced an atypical element into the reactions obtained.

Among the sources of material used in these experiments, normal skin is of particular interest. Floch (1956) has also reported the occurrence of similar reactions using suspensions of normal skin, and the possibility arises that the tissue components in standard lepromin are not as inert as has been supposed. The subject obviously calls for further study, for these findings if generally confirmed could be of profound significance in more than one direction. We have repeated the first experiment reported by Kooij and Gerritsen, using additional controls, and as it has been suggested to us that the findings may provide an incentive to others to undertake similar work, we present them here.

\section{Patients}

Fif ty leprosy patients took part in the experiment. Particular care was taken to classify them accurately, and on a basis of clinical bacteriological and histological findings, they were classified as, lepromatous 10 , indeterminate 3 , borderline 10 , minor tuberculoid 17, major tuberculoid 10. All were segregated under close observation and were receiving chemotherapy.

\section{Materials}

(a) Normal skin preparation

In order to merit the description "normal" it was felt desirable that the skin used should be obtained only by biopsy. Specimens of skin removed during the course of surgical operations at a general hospital were autoclaved immediately after excision, sealed and despatched to us, and kept in a refrigerator until needed. The method of preparation was identical with that recommended for standard lepromin, following Wade's modification of the original Hayashi- 
Mitsuda method. Subcutaneous fat was scraped from the specimens, which were then pooled, cut up and ground fine in a mortar with the addition of saline up to $20 \mathrm{ccs}$ per gramme of skin. The suspension was filtered through nylon cloth. The residue was not used again. $0.5 \%$ phenol was added to the filtrate, which was transferred to rubber capped bottles, and these were again autoclaved and labelled. Smears of this preparation made for checking purposes after its use for inoculation showed no acid fast bacilli.

(b) Lepromin

It was felt desirable to provide additional controls in this experiment by using both standard and refined lepromin, prepared from the same material. A fresh sample of each was prepared from the same specimens of lepromatous skin. These were cut into two after autoclaving, and standard Mitsuda-Wade lepromin prepared from one half by the method stated above, while the other half was used for the preparation of a refined antigen by Lowe's simplification of the Dharmendra technique. This has been described elsewhere by Lowe (1953), but is described again here for convenience as follows.

After autoclaving, fat was scraped off the specimens of leproma, which were then cut in very small pieces and ground in a mortar with small amounts of chloroform, the chloroform extract being pipetted off from time to time and replaced with fresh chloroform. This process was repeated, until the chlorof orm extract being pipetted off contained very few bacilli. The residue in the mortar was then discarded, and the chloroform removed from the extract by evaporation. The syrupy residue was then ground with carbol saline, $0.5 \%$, and the aqueous layer pipetted off into a separating funnel, where it could be separated again more perfectly from the fatty material present. The substrate was run through nylon cloth into rubber capped bottles, autoclaved, labelled, and kept in the refrigerator until required.

Lepromin refined by this method has been in standard use in this laboratory for several years. Its significance from the standpoint of this experiment lies in its almost complete freedom from tissue components, while at the same time the bacilli are not denatured to any marked extent.

The new batch was standardised both directly and biologically against the standard in regular use, and found to possess an activity fully up to this standard.

\section{Method}

The three preparations used in this experiment were thus, (a) Standard Mitsuda-Wade lepromin, (b) Refined DharmendraLowe lepromin, (c) Normal skin preparation.

$0.1 \mathrm{cc}$. of each of these was inoculated into the skin on the inner side of the upper arm in each of the 50 volunteers at sites one below the other. $0.1 \mathrm{cc}$. of $0.5 \%$ carbol saline was injected at the same time 
as a control into the skin of the other arm. Reactions were measured after 24 and 48 hours, on the seventh day, and then weekly up to the thirty-fifth day, and readings were checked before being recorded.

\section{Results}

(a) Fernandez Reaction

Forty-eight hour readings are presented in Table I, classified both according to the accepted degrees of positivity in the Fernandez Reaction, and according to the type of leprosy displayed by those concerned.

The carbol saline control inoculations provided sufficient irritation to produce areas of oedema in a considerable number of patients, small but still measurable after 48 hours. Due regard is paid to this by indicating the excess over the control readings exhibited by the test inoculations. Totals for this excess in millimetres are given in Table II in the various groups of patients.

Both Tables bring out the close similarity between the two lepromins in the Fernandez reactions they elicited, both in size of reactions and their pattern in the various types of leprosy. Both were active and behaved normally, with reactions increasing in intensity towards the major tuberculoid group.

There is an obvious contrast between them and the normal skin preparation in this respect, made particularly clear in Table II. The normal skin preparation had only a very slight capacity to evoke the Fernandez response, with an insignificant increase in activity in tuberculoid cases.

These findings differ from those of Kooij and Gerritsen, though in a later publication in which details are given by these authors (1957), there appears to have been little difference between their lepromatous and tuberculoid case in the Fernandez reactions they produced to a concentrated skin preparation.

\section{(b) Mitsuda Reaction}

Readings for the Mitsuda reaction are given in Table III, classified in the same way as those in Table I. As is usually the case, the date when the peak reaction was attained varied from one patient to another, in some at 21 days, in others at 28 days. The peak readings are recorded here. This gives a more accurate picture of the reactions obtained than would have resulted from 28 days readings only. No readings are given for controls, for they were negative in every case.

A comparison between the three preparations can also be made by recording the total of the reactions produced in the various classes of patients. This is given in Table IV.

The standard lepromin was obviously a highly active preparation, giving intensely positive readings in major tuberculoid cases, strongly positive readings in minor tuberculoid cases, and positive findings in both borderline and indeterminate cases. 
TABLE 1

Fernandez Reactions in Millimetres

\begin{tabular}{|c|c|c|c|c|c|}
\hline $\begin{array}{l}\text { LePromatous CASES } \\
\text { 10 Patients } \\
\text { 1. Standard Lepromin } \\
\text { 2. Refined Lepromin } \\
\text { 3. Normalskinpreparation } \\
\text { 4. Controls }\end{array}$ & $\begin{array}{c}\text { Below } 5 \\
6 \\
6 \\
9 \\
10\end{array}$ & $\begin{array}{r}5-9 \\
4 \\
4 \\
1 \\
0\end{array}$ & $\begin{array}{c}10-14 \\
0 \\
0 \\
0 \\
0\end{array}$ & $\begin{array}{c}15-19 \\
0 \\
0 \\
0 \\
0\end{array}$ & $\begin{array}{c}20 \text { plus } \\
0 \\
0 \\
0 \\
0\end{array}$ \\
\hline $\begin{array}{l}\text { INDETERMINATE CASES } \\
3 \text { Patients } \\
\text { 1. Standard Lepromin } \\
\text { 2. Refined Lepromin } \\
\text { 3. Normalskin preparation } \\
\text { 4. Controls }\end{array}$ & $\begin{array}{l}1 \\
1 \\
2 \\
3\end{array}$ & $\begin{array}{l}1 \\
1 \\
1 \\
0\end{array}$ & $\begin{array}{l}1 \\
1 \\
0 \\
0\end{array}$ & $\begin{array}{l}0 \\
0 \\
0 \\
0\end{array}$ & $\begin{array}{l}0 \\
0 \\
0 \\
0 \\
\end{array}$ \\
\hline $\begin{array}{l}\text { BORDERLINE CASES } \\
\text { 10 Patients } \\
\text { 1. Standard Lepromin } \\
\text { 2. Refined Lepromin } \\
\text { 3. Normal skin preparation } \\
\text { 4. Controls }\end{array}$ & $\begin{array}{r}2 \\
2 \\
7 \\
10\end{array}$ & $\begin{array}{l}6 \\
7 \\
3 \\
0\end{array}$ & $\begin{array}{l}2 \\
1 \\
0 \\
0\end{array}$ & $\begin{array}{l}0 \\
0 \\
0 \\
0\end{array}$ & $\begin{array}{l}0 \\
0 \\
0 \\
0\end{array}$ \\
\hline $\begin{array}{l}\text { MINOR TUBERCULOID CASES } \\
17 \text { Patients } \\
\text { 1. Standard Lepromin } \\
\text { 2. Refined Lepromin } \\
\text { 3. Normalskinpreparation } \\
\text { 4. Controls }\end{array}$ & $\begin{array}{r}1 \\
1 \\
10 \\
12\end{array}$ & $\begin{array}{r}9 \\
12 \\
6 \\
4\end{array}$ & $\begin{array}{l}6 \\
4 \\
1 \\
1\end{array}$ & $\begin{array}{l}1 \\
0 \\
0 \\
0\end{array}$ & $\begin{array}{l}0 \\
0 \\
0 \\
0\end{array}$ \\
\hline $\begin{array}{l}\text { MAJOR TUberculoid CASES } \\
\text { 10 Patients } \\
\text { 1. Standard Lepromin } \\
\text { 2. Refined Lepromin } \\
\text { 3. Normal skin preparation } \\
\text { 4. Controls }\end{array}$ & $\begin{array}{r}0 \\
0 \\
6 \\
10\end{array}$ & $\begin{array}{l}4 \\
4 \\
4 \\
0\end{array}$ & $\begin{array}{l}4 \\
4 \\
0 \\
0\end{array}$ & $\begin{array}{l}2 \\
2 \\
0 \\
0\end{array}$ & $\begin{array}{l}0 \\
0 \\
0 \\
0\end{array}$ \\
\hline
\end{tabular}

TABLE II

Fernandez Reaction: Excess in Millimetres Over Control Readings

\begin{tabular}{|c|c|c|c|c|c|c|c|c|c|c|c|c|c|c|c|}
\hline & \multicolumn{3}{|c|}{$\begin{array}{l}\text { LEPRO- } \\
\text { MATOUS } \\
10 \text { cases }\end{array}$} & \multicolumn{3}{|c|}{$\begin{array}{l}\text { INDETER- } \\
\text { MINATE } \\
3 \text { cases }\end{array}$} & \multicolumn{3}{|c|}{$\begin{array}{l}\text { BORDER- } \\
\text { LINE } \\
10 \text { cases }\end{array}$} & \multicolumn{3}{|c|}{$\begin{array}{l}\text { MINOR } \\
\text { TUBERC. } \\
17 \text { cases }\end{array}$} & \multicolumn{3}{|c|}{$\begin{array}{l}\text { MAJOR } \\
\text { TUBERC. } \\
10 \text { cases }\end{array}$} \\
\hline & STD & REF & NSP & STD & REF & NSP & STD & REF & NSP & STD & REF & NSP & STD & REF & NSP \\
\hline $\begin{array}{l}\text { Total } \\
\text { Average }\end{array}$ & $\begin{array}{l}15 \\
1.5\end{array}$ & $\begin{array}{r}14 \\
1.4\end{array}$ & $\begin{array}{r}5 \\
0.5\end{array}$ & $\begin{array}{r}10 \\
3.3\end{array}$ & $\begin{array}{r}8 \\
2.7\end{array}$ & $\begin{array}{r}4 \\
1.3\end{array}$ & $\begin{array}{r}33 \\
3.3\end{array}$ & $\begin{array}{r}29 \\
2.9\end{array}$ & 0.1 & \begin{tabular}{|c|}
77 \\
4.5
\end{tabular} & $\begin{array}{r}82 \\
4.8\end{array}$ & $\begin{array}{r}12 \\
0.7\end{array}$ & $\begin{array}{l}79 \\
7.9\end{array}$ & $\begin{array}{r}81 \\
8.1\end{array}$ & $\begin{array}{r}16 \\
1.6\end{array}$ \\
\hline
\end{tabular}

sTD Standard Lepromin

REF Refined Lepromin

NSP Normal skin preparation.

The refined lepromin produced reactions following the same pattern but at a lower level of activity. This was as expected, though the loss of activity was emphasised by the unusually high activity of the standard lepromin. With the refined preparation reactions were generally smaller in size, and in a proportion of the indeterminate and borderline groups of patients they were reduced to a negative level.

Reactions were also produced by the normal skin preparation, and these undoubtedly followed the same pattern, though at a still 
TABLE III

Mitsuida Reactions in Millimetres

\begin{tabular}{|c|c|c|c|c|c|}
\hline $\begin{array}{l}\text { LEPROMATOUS CASES } \\
\text { 10 Patients } \\
\text { 1. Standard Lepromin } \\
\text { 2. Refined Lepromin } \\
\text { 3. Normal skin preparation }\end{array}$ & $\begin{array}{c}\text { Below } 3 \\
10 \\
10 \\
10\end{array}$ & $\begin{array}{r}3-4 \\
0 \\
0 \\
0\end{array}$ & $\begin{array}{r}5-7 \\
0 \\
0 \\
0\end{array}$ & $\begin{array}{r}8-9 \\
0 \\
0 \\
0\end{array}$ & $\begin{array}{c}10 \text { plus } \\
0 \\
0 \\
0\end{array}$ \\
\hline $\begin{array}{l}\text { INDETERMINATE CASES } \\
3 \text { Patients } \\
\text { 1. Standard Lepromin } \\
\text { 2. Refined Lepromin } \\
\text { 3. Normal skin preparation }\end{array}$ & $\begin{array}{l}0 \\
3 \\
3\end{array}$ & $\begin{array}{l}0 \\
0 \\
0\end{array}$ & $\begin{array}{l}1 \\
0 \\
0\end{array}$ & $\begin{array}{l}0 \\
0 \\
0\end{array}$ & $\begin{array}{l}2 \\
0 \\
0\end{array}$ \\
\hline $\begin{array}{l}\text { BORIDERLINE CASES } \\
\text { 10 Patients } \\
\text { 1. Standard Lepromin } \\
\text { 2. Refined Lepromin } \\
\text { 3. Normal skin preparation }\end{array}$ & $\begin{array}{l}0 \\
4 \\
8\end{array}$ & $\begin{array}{l}1 \\
3 \\
2\end{array}$ & $\begin{array}{l}6 \\
3 \\
0\end{array}$ & $\begin{array}{l}0 \\
0 \\
0\end{array}$ & $\begin{array}{l}3 \\
0 \\
0\end{array}$ \\
\hline $\begin{array}{l}\text { MINOR TUBERCULOID CASES } \\
\text { 17 Patients } \\
\text { 1. Standard Lepromin } \\
\text { 2. Refined Lepromin } \\
\text { 3. Normal skin preparation }\end{array}$ & $\begin{array}{l}0 \\
4 \\
4\end{array}$ & $\begin{array}{l}1 \\
0 \\
1\end{array}$ & $\begin{array}{r}0 \\
8 \\
12\end{array}$ & $\begin{array}{l}2 \\
4 \\
0\end{array}$ & $\begin{array}{r}14 \\
1 \\
0\end{array}$ \\
\hline $\begin{array}{l}\text { MAJOR TUBERCULOID CASES } \\
\text { 10 Patients } \\
\text { 1. Standard Lepromin } \\
\text { 2. Refined Lepromin } \\
\text { 3. Normal skin preparation }\end{array}$ & $\begin{array}{l}0 \\
0 \\
0\end{array}$ & $\begin{array}{l}0 \\
0 \\
1\end{array}$ & $\begin{array}{l}0 \\
7 \\
6\end{array}$ & $\begin{array}{l}0 \\
1 \\
3\end{array}$ & $\begin{array}{r}10 \\
2 \\
0\end{array}$ \\
\hline
\end{tabular}

TABLE IV

Mitsuda Reaction: Total Readings in Millimetres

\begin{tabular}{|c|c|c|c|c|c|}
\hline & $\begin{array}{l}\text { LEPRO- } \\
\text { MATOUS } \\
10 \text { cases }\end{array}$ & $\begin{array}{l}\text { INDETER- } \\
\text { MINATE } \\
3 \text { cases }\end{array}$ & $\begin{array}{l}\text { BORDER } \\
\text { LINE } \\
10 \text { cases }\end{array}$ & $\begin{array}{l}\text { MINOR } \\
\text { TUBERC. } \\
17 \text { cases }\end{array}$ & $\begin{array}{l}\text { MAJOR } \\
\text { TUBERC. } \\
10 \text { cases }\end{array}$ \\
\hline $\begin{array}{l}\text { Total } \\
\text { Average }\end{array}$ & $\begin{array}{ccc}\text { STD } & \text { REF } & \text { NSP } \\
6 & 2 & 0 \\
0.6 & 0.2 & 0\end{array}$ & $\begin{array}{ccc}\text { STD } & \text { REF } & \text { NSP } \\
33 & 4 & 0 \\
11.0 & 1.3 & 0\end{array}$ & $\begin{array}{rrr}\text { STD } & \text { REF } & \text { NSP } \\
66 & 24 & 5 \\
6.6 & 2.4 & 0.5\end{array}$ & \begin{tabular}{|ccc} 
STD & REF & NSP \\
207 & 101 & 73 \\
12.2 & 6.0 & 4.3
\end{tabular} & \begin{tabular}{|ccc} 
STD & REF & NSP \\
183 & 68 & 63 \\
18.3 & 6.8 & 6.3
\end{tabular} \\
\hline
\end{tabular}

STD Standard Lepromin REF Refined Lepromin NSP Normal skin preparation.

lower level of activity. Without exception lepromatous cases gave negative reactions. Major tuberculoid cases gave a definite macroscopic reaction in every case. Minor tuberculoid cases also gave macroscopic reactions, though some of these were very small, less than $3 \mathrm{~mm}$. in diameter in $24 \%$ of cases, though here identical findings were obtained with the refined lepromin. For the most part indeterminate and borderline cases gave negative reactions.

As the refined lepromin often produced reactions similar in size to those evoked by the normal skin preparation, a comparison of features of the reactions other than that of size could easily be made. It was impossible to detect any difference in appearance or texture. In their development the reactions usually ran parallel with one another, an early peak in the lepromin reaction being associated with an early peak in the reaction to normal skin, late peak reactions also 
being similarly associated. Where their decline was concerned, the reactions to refined lepromin showed some tendency to subside earlier than the reactions to normal skin and standard lepromin. Clinically the reactions were thus closely similar, and this similarity was also found in histological preparations of the reactions in four individuals at the fortieth day.

\section{Discussion}

There can be no doubt that the preparation of normal skin used in this experiment possessed a capacity to induce skin reactions which was distinctive, resembling a weak lepromin in its capacity to induce the Mitsuda type of response, but lacking the capacity of lepromin to induce the Fernandez type of response to any significant extent.

The question immediately arose as to whether there had been any opportunity for the contamination of the normal skin preparation with lepromin or lepromatous tissue in the laboratory. A careful review of the method of preparation, labelling and preservation made this exceedingly unlikely. Attention was paid to the glassware used, as it is known that tuberculin can adhere to glass and contaminate a preparation made subsequently in the same vessel.

The mortar used for the normal skin preparation had been used in the past for preparing lepromin, but it had been thoroughly scrubbed and autoclaved before being used, and the extreme unlikelihood of any contamination from this source is evidenced both by the failure of the preparation to induce Fernandez reactions and the absence of acid fast bacilli in smears made from it. The utmost care was taken in labelling and preservation. New syringes and needles were used for the inoculations. By all reasonable standards contamination can be ruled out as a practical possibility.

It follows that we can at any rate in part confirm the findings of Kooij and Gerritsen that lepromatous tissue is not essential for the production of the Mitsuda reaction. By suitable adjustment of the standards for the various grades of positivity, the preparation of normal skin used in this experiment could have been used instead of lepromin to distinguish positive from negative Mitsuda reactors.

It would be interesting to observe the effects of concentrating such a preparation. We may note here that although at first Kooij and Gerritsen observed no increase in activity by concentrating their preparation, (though different subjects appear to have been used for testing the concentrated material), the marked reactions they obtained later resulted from the inoculation of concentrated material.

The resemblance of the normal skin preparation to refined lepromin in the Mitsuda reactions it produced is also worthy of note. Where the Mitsuda reaction alone is concerned, it is questionable whether the refined lepromin had any real advantage over it. It was in Fernandez reactivity that the difference between the two was apparent. 
It remains to be seen whether the activity displayed by the specimens of normal skin used in this experiment is a freak finding, or illustrates a general principle. The possibility cannot be ruled out that even if contamination with lepromatous tissue can be ignored apparently skin may contain unsuspected antigens such as microfilariae and fungi which are capable in appropriate conditions of inducing a tuberculoid type of reaction. The likelihood that such things could have induced the reactions observed is of course exceedingly remote, but it would be useful in future studies to have histological evidence for the exclusion of such possibilities.

It is not proposed here to discuss the pathological processes which may underlie these reactions. The data available are not sufficient for the drawing of conclusions. More experiment is needed with histological control. Kooij and Gerritsen have rendered useful service in drawing attention to the existence of these interesting reactions. Their thorough investigation is now called for.

\section{Summary}

An experiment is described in which standard lepromin, refined lepromin and a normal skin preparation were inoculated into the skin of 50 leprosy patients of various types in an attempt to confirm the findings of Kooij and Gerritsen that a normal skin preparation could induce both Fernandez and Mitsuda reactions. It was found that the normal skin preparation used had no appreciable capacity to induce Fernandez reactions, but did induce reactions indistinguishable from Mitsuda reactions in tuberculoid cases of leprosy. These were decidedly smaller than those induced by standard lepromin, a little smaller than those produced by refined lepromin, but followed the same pattern. The Kooij and Gerritsen observations were thus in part confirmed, and the subject needs further study.

\section{Acknowledgments}

Grateful thanks are due to Dr. J. Gower of the Queen Elizabeth Hospital, Umuahia, who kindly supplied the material from which the normal skin preparation was made, and to the patients who volunteered to take part in this experiment. Thanks are also due to Dr. K. Seal, Leprosy Adviser, and Dr. Onwu, C.V.O., Director of Medical Services, Eastern Region, Nigeria, for permission to publish.

\section{REFERENCES}

1. FLOCH, H. (1956) Internat. J. Leprosy 24, 292-296.

2. Kinnear Brown, J. A., Murray Short, G. Blenska, W. (1957) Internat. J. Leprosy 25, 271.

3. KoolJ, R. \& Gerritsen, Th. (1956) Internat. J. Leprosy 24, 171-181.

4. KooiJ, R. \& Gerritsen, Th. (1958) Dermatologica 116: 1-27

5. KoOIJ, R. \& Gerritsen, Th. (1957) Internat. J. Leprosy 25, 274.

6. Lowe, J. \& McNulty (1953) Leprosy Review 24, 61-89. 